\title{
Leptodactylus ocellatus (Amphibia): Mechanism of Defense in the Skin and Molecular Phylogenetic Relationships
}

JOÃO MANOEL ALMEIDA LEITE JR ${ }^{1}$, LUCIANO PAULINO SILVA², ROBERTA ROCHA SILVA-LEITE ${ }^{1,3}$, ANA STELLA FERRARI ${ }^{4}$, SERGIO EUSTÁQUIO NORONHA ${ }^{4}$, HELIO RICARDO SILVA ${ }^{5}$, CARLOS BLOCH JR ${ }^{2}$, AND JOSÉ ROBERTO DE SOUZA DE ALMEIDA LEITE ${ }^{1 *}$
${ }^{1}$ Núcleo de Pesquisa em Biodiversidade e Biotecnologia, Campus Ministro Reis Velloso (CMRV), Universidade Federal do Piaui-UFPI, Parnaiba, Piaui, $\mathrm{Pl}$, Brazil
${ }^{2}$ Laboratório de Espectrometria de Massa-LEM, EMBRAPA Recursos Genéticos e Biotecnologia, Brasilia, DF, Brazil
${ }^{3}$ Programa de Pós-graduação em Desenvolvimento e Meio Ambiente, Núcleo de Referência em Ciências Ambientais do Trópico Ecotonal do Nordeste (TROPEN), Universidade Federal do Piauí-UFPI, Teresina, Piauí, PI, Brazil
${ }^{4}$ Laboratório de Geoprocessamento, EMBRAPA Recursos Genéticos e Biotecnologia, Brasilia, DF, Brazil
${ }^{5}$ Laboratório de Herpetologia, Departamento de Biologia Animal, Instituto de Biologia, Universidade Federal Rural do Rio de Janeiro, UFRRJ, Seropédica, RJ, Brazil

ABSTRACT Amphibian antimicrobial peptides have been known for many decades and several of them have
already been isolated. However, the number of species investigated is still small. Herein, we report
on the skin secretions of Leptodactylus ocellatus, which were extracted by mild electrical
stimulation and its semi-preparative reverse-phase chromatography was resolved in more than 30
fractions. Among these fractions, two novel antimicrobial peptides were isolated and their amino
acid sequences determined by de novo sequencing. The ocellatins-5 and -6 (21 and 22 amino acid
residues, respectively) are amidated at the C-terminus. Ocellatins inhibited the growth of reference
strains of both Gram-negative bacteria (Escherichia coli) and Gram-positive bacteria
(Staphylococcus aureus) with minimal inhibition concentration values in the range of
32-128 $\mu$ g/mL. The amino acid sequence of the peptides shows structural similarity with members
of the antimicrobial peptides found in the skin secretion of other leptodactylid frogs. This
observation is consistent with the hypothesis that many frog skin antimicrobial peptides are
related evolutionarily, having arisen from multiple duplications of an ancestral gene that existed
before the radiation of the different species. J. Exp. Zool. 313A:1-8, 2010. C 2009 Wiley-Liss, Inc.

The release into skin secretions of peptides with antibacterial and antifungal properties is a feature of several species of anuran amphibians. These peptides are believed to protect the organism against invasion by pathogenic microorganisms and constitute a component of the innate immunity (Nicolas and Mor, '95; King et al., 2005; Hoffmann et al., 2007).

One of the most diverse and abundant frogs in the Neotropics is that of the genus Leptodactylus Fitzinger, 1826, which is divided into four species groups (Heyer and Reid, 2003). Despite the great diversity and wide distribution of this genus, studies on
Grant Sponsor: CNPq (Universal); Empresa Brasileira de Pesquisa Agropecuária (EMBRAPA).

* Correspondence to: Dr. José Roberto de Souza de Almeida Leite, Grupo de Biodiversidade e Biotecnologia, Campus Ministro Reis Velloso (CMRV), Universidade Federal do Piauí-UFPI, Rua Pinheiro Machado Reis Velloso, Parnaiba, Piaui, PI 64202-020, Brazil. E-mail: jrsaleite@gmail.com, jrleite@ufpi.br

Received 11 November 2008; Revised 25 March 2009; Accepted 12 May 2009

Published online 8 September 2009 in Wiley InterScience (www. interscience.wiley.com). DOI: 10.1002/jez.551 
the skin secretion are rare, studied up to now: fallaxin (Leptodactylus fallax-Rollins-Smith et al., 2005), laticeptin ( $L$. laticeps-Conlon et al., 2006), ocellatins (L. ocellatus-Nascimento et al., 2004, 2007), pentadactylin (L. pentadactylus-King et al., 2005) and syphaxins (L. syphax-Dourado et al., 2007). L. laticeps, L. ocellatus, L. pentadactylus and L. syphax are South American species, whereas L. fallax is from Central America.

The degree of molecular heterogeneity of the dermal peptides is high. Consequently, determination of their amino acid sequences can complement other types of molecular investigations relating to amphibian taxonomy and phylogeny, such as comparisons of nucleotide sequences of orthologous genes (Conlon et al., 2004).

With only six species, the L. ocellatus (Linnaeus, 1758) group is the least diverse species group of Leptodactylus. In spite of this limited diversity, this group still poses several important taxonomic problems. Whereas other species groups of Leptodactylus have been the subject of comprehensive taxonomic research, the L. ocellatus group has not. The only complete review of this group was carried out by Gallardo ('64) and is considered out of date (De la Riva and Maldonado, '99).

The molecular heterogeneity of ocellatins may be exploited as an aid to taxonomic and phylogenetic classification and in the design of peptide-based antimicrobial agents. The molecular diversity in the present-day species is a consequence of multiple duplications of this ancestral gene during radiation of the species and within individual species (Conlon et al., 2006).

This study describes the isolation, characterization and antimicrobial activity evaluation of two novel ocellatins (named ocellatins-5 and -6) and some truncated peptides from the skin
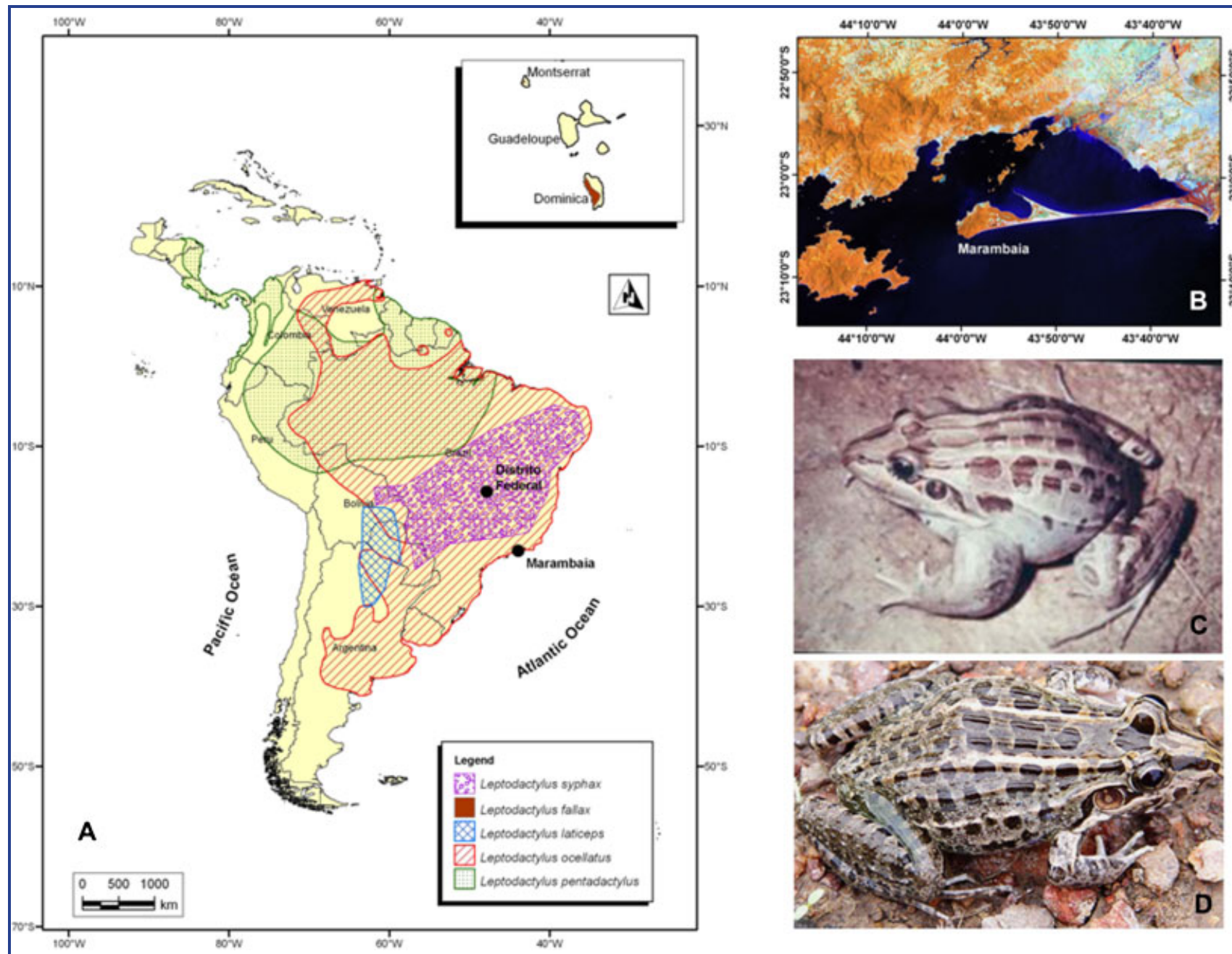

Figure 1. (A) Geographic distribution of Leptodactylus genus cited in this study in South America (IUCN, 2008). (B) Map of Marambaia Island (square). Enlarged, Marambaia Island with part of the restinga and indication of sampling sites. (C) Leptodactylus ocellatus from the Brazilian Cerrado, Brasilia, Brazil (photo: José Roberto Leite). (D) L. ocellatus, Rio de Janeiro State, Brazil (photo: S. P. Carvalho-e-Silva). 
secretions of L. ocellatus collected in the Marambaia Island (RJ/ Brazil). The molecular diversity of the antimicrobial peptides among the specimens studied from two localities was analyzed and we discuss the light they shed on these frogs' phylogenetic relationships.

\section{MATERIAL AND METHODS}

Amphibians, Skin Secretions and Study Area

Adult specimens of $L$. ocellatus $(n=4)$ were collected in Marambaia Island (Rio de Janeiro, Southeastern, Brazil) under the Instituto Brasileiro do Meio Ambiente e dos Recursos Renováveis (IBAMA) license and process number 240/2005CGFAU/LIC. The skin secretion was obtained through a mild electrical stimulation. The skin was washed with ultrapure water and the secretion was dried and frozen. Marambaia $\left(23^{\circ} 04^{\prime} \mathrm{S}\right.$ and $43^{\circ} 53^{\prime} \mathrm{W}$, Fig. $1 \mathrm{~A}$ and B) presents a marked spatial heterogeneity, including rain forests on the hills (Atlantic Forest), restinga (long sand bars connecting the hills to the continent, covered with open vegetation) and mangrove (Menezes and Araújo, 2005; Carvalho et al., 2007).

\section{Peptide Purification}

The skin secretion was dissolved in $0.1 \%$ trifluoroacetic acid (TFA) aqueous solution and filtered. The extract was submitted to RP-HPLC [218 TP 510 and 218 TP 54 C18 Vydac $\left(C_{18}, 5\right.$ mm, 4.6 $\mathrm{mm}$ i.d. $\times 250 \mathrm{~mm}$ ) (Interchim, Montluçon, France)] using a linear gradient of acetonitrile/TFA $0.1 \%(\mathrm{v} / \mathrm{v})$ rising from 0 to $100 \%$ in $55 \mathrm{~min}$ in semi-preparative mode. The experiments were monitored at 216 and $280 \mathrm{~nm}$. Fractions were collected manually and lyophilized.

\section{Mass Spectrometry and de Novo Sequencing}

The molecular mass determination and de novo sequencing of peptides were performed by using an UltraFlex II MALDI-TOF/ TOF Mass Spectrometer (Bruker Daltonics, Billerica, MA). Chromatographic fractions were dissolved in an $\alpha$-cyano-4hydroxycinnamic acid matrix solution (1:3, v/v), spotted onto a MALDI target plate and dried at room temperature for $15 \mathrm{~min}$. The peptide monoisotopic masses were obtained in reflector mode with external calibration, using the Peptide Calibration Standard for Mass Spectrometry calibration mixture (up to 4,000 Da mass range, Bruker Daltonics). MS/MS spectra were obtained by LIFT/CID fragmentation. Primary structures of the peptides were manually interpreted and isomeric and isobaric residues were assigned based on the high-energy fragmentation ions according to Williams and Alterman (2007) and Gogichaeva et al. (2007). FlexAnalysis 2.4 (Bruker Daltonics), Data Explorer 4.5 (Applied Biosystems, Foster City, CA) and MassLynx 4.0 software (Micromass, Manchester, UK) softwares were used to interpret mass spectra.

\section{Sequence Analysis}

The search for similar sequences was performed with FASTA 3 program (http://www.ebi.ac.uk/fasta33/) using Swiss-Prot databank. New ocellatins were also off-line compared with fallaxin, pentadactylin, laticeptin and other ocellatins using information available in the current literature (King et al., 2005; Rollins-Smith et al., 2005; Conlon et al., 2006), but unavailable in major databanks. Clustal W tool (http://www.ebi.ac.uk/clustalw/) was used to calculate the identity and similarity scores among the peptides. Evolutionary relationship prediction among similar peptides was done using Clustal $\mathrm{W}$ tool using the neighbor joining method (Saitou and Nei, '87).

\section{Peptide Synthesis}

Peptides were synthesized on a Pioneer Automatic Peptide Synthesizer (Applied Biosystems) and purified as previously described (Brand et al., 2002).

Antimicrobial Activity

Peptide purity was attested by mass spectrometry and the concentrations of the purified ocellatins were calculated by measuring the absorbance at 215 and $225 \mathrm{~nm}$ (Lai et al., 2001). The activity of ocellatins- 5 and -6 toward Gram-positive and Gram-negative bacteria was tested by the broth microdilution assay, according to the National Committee for Clinical Laboratory Standards ('99). The bacterial strains used were Escherichia coli ATCC 25922 and Staphylococcus aureus ATCC 29213. Bacterial colonies were inoculated in Mueller-Hinton sterile liquid medium and were left to grow at $37^{\circ} \mathrm{C}$ overnight. An aliquot $(200 \mu \mathrm{L})$ was transferred to a fresh medium and incubated for $8 \mathrm{~h}$ in order to obtain the cells at mid-logarithmic phase. The initial inoculum was $10^{8}$ colony forming units $/ \mathrm{mL}$. The minimal inhibitory concentrations (MICs) were calculated through the average of the lowest peptide concentration that completely inhibited the bacterial growth. The initial inoculum was adjusted to match 0.5 in the McFarland scale.

\section{Distributional Modeling and Ecological Niche Modeling}

Ecologic niches, potential geographic distributions and distributional data for L. ocellatus (Cerrado Region and Marambaia Island) were modeled using the Genetic Algorithm for Rule-Set Prediction (GARP). In general, GARP focuses on modeling ecologic niches (the conjunction of ecologic conditions within which a species can maintain populations). GARP relates ecologic characteristics of known occurrence points to those of points randomly sampled from the rest of the study region, seeking to develop a series of decision rules that best summarize those factors associated with the species' presence. GARP includes several distinct algorithms for niche modeling in an artificialintelligence-based approach (Costa et al., 2002).

All modeling in this study was carried out on a desktop implementation of GARP, which is in a $\beta$-testing stage for 
eventual public release. This implementation offers muchimproved flexibility in choosing predictive environmental/ ecologic geographic information system (GIS) data coverage. In this case, we used 22 data layers: elevation, slope and aspect from the US Geological Survey's Hydro-1K data set (http://edcdaac.usgs.gov/gtopo30/hydro/); aspects of climate including annual mean cloud cover, daily temperature range, minimum and maximum annual precipitation, vapor pressure, wet days and wind speed plus monthly data for precipitation and the two temperature measures from the Intergovernmental Panel on Climate Change (http://www.ipcc.ch/); tree cover and land use/ land cover from the Geological Survey's Global Land Cover Database (http://edcdaac.usgs.gov/glcc/glcc.html).

Variable combinations predicted present by the GARP rules were identified in the test states and used to predict species' occurrences in those states. Resulting geographic predictions were exported as ASCII raster grid files for use in ArcView (version 3.2). In ArcView, the test occurrence data were overlain on the predictions for the 20 test states. Numbers of points correctly and incorrectly predicted by GARP were used as observed values. Expected numbers were taken as the test sample size multiplied by the proportional area predicted present in test states. A $\chi^{2}$ analysis for each species was used to assess the model significance. To permit the visualization of the ecological niche model, the eight ecological coverages were crossed (Combine option in ArcView) with the distributional prediction to produce a table of predicted presences and absences across environmental combinations (Peterson, 2001).

\section{RESULTS AND DISCUSSION}

\section{Purification and Characterization}

The fractionation of the crude skin secretion of $L$. ocellatus by semi-preparative RP-HPLC yielded more than 30 fractions (Fig. 2). Monoisotopic molecular masses of novel ocellatins (ocellatins-5 and -6) and five truncated forms were determined and these peptides had their primary structures obtained by de novo sequencing (sequence identification is given in Table 1). FASTA searches revealed high sequence identity among antimicrobial peptides from Leptodactylus genus (Table 1). Ocellatin5 shows $61 \%$ identity to ocellatin-6. Sequence similarity searches showed up to $36 \%$ sequence identity of ocellatin- 5 to ocellatin- 1 (L. ocellatus on the Brazilian Cerrado). They differ by amino acid residues in the $\mathrm{N}$-terminal region, but many substitutions are conservative (Table 1).

The similarities among all ten leptodactylid antimicrobial peptides were supported by the Clustal $\mathrm{W}$ phylogram and these new peptides are the most different among all others for this family of amphibians, with major changes in the N-terminal region (Fig. 4). It seems that the C-terminal amidation is highly conserved in the Leptodactylus genus antimicrobial peptide family.

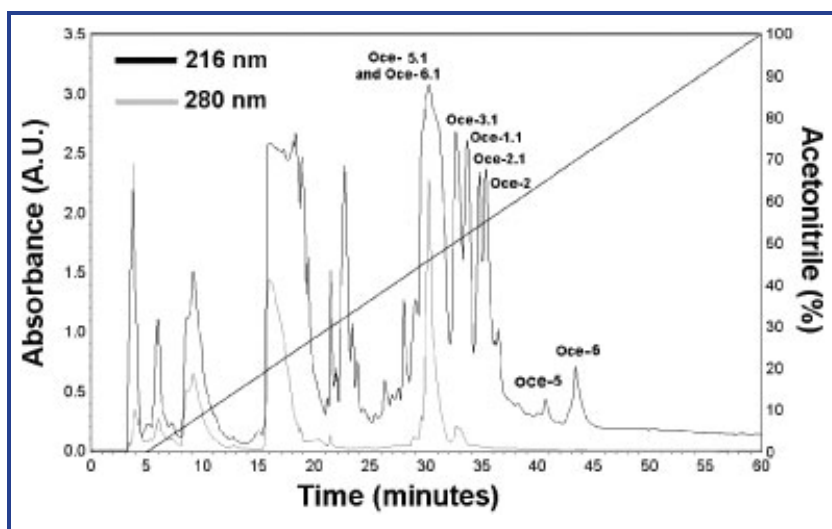

Figure 2. Fractionation of the total skin secretion lyophilized crude extract from L. ocellatus. The crude extract was loaded onto a C18 Vydac 218 TP510 $(10 \mathrm{~mm} \times 250 \mathrm{~mm})$ column and equilibrated with $0.1 \%$ trifluoroacetic acid. The peptide elution was performed using an acetonitrile with $0.1 \%$ trifluoroacetic acid solution with $2.5 \mathrm{~mL} / \mathrm{min}$ flow rate. The absorbance was monitored simultaneously at two wavelengths, 216 and $280 \mathrm{~nm}$.

The ocellatins described in this study were isolated from the skin secretion of specimens from Ilha da Marambaia (Fig. 1B), coastal region of the Atlantic Forest in the State of Rio de Janeiro, Brazil. Ocellatins-1, $-2,-3$ and -4 were isolated from the specimens of the Brazilian savannah (Nascimento et al., 2004, 2007). Despite the wide distribution of the species $L$. ocellatus (Fig. 1A), also including the two studied regions, a great difference was observed in the amino acid sequence of this class of antimicrobial peptides isolated from the same species in the two localities.

For example, the conserved pattern for the antimicrobial peptides of this anuran family was always $\mathrm{N}-\mathrm{GV} \ldots\left(\mathrm{NH}_{2}\right)$ for the $\mathrm{N}$-terminal region with amidation for the C-terminal end; the pattern of amidation was maintained but the beginning of the sequence was altered to $\mathrm{N}-\mathrm{AV} \ldots\left(\mathrm{NH}_{2}\right)$, interrupting the logical sequence of the first amino acid that was always Gly.

Leptodactylids are among the most widely distributed anuran families in South America, and especially L. ocellatus occupies a wide geographical area, including not only Brazil but also Argentina, Paraguay and Uruguay. An extensive literature has been published about these species mainly because of their complex reproductive morphological behavior. The morphological pattern for this species changes depending on the locality, and some authors argue about the possibility of a species complex for the group of species denominated as L. ocellatus (Fig. 1C and D). Interestingly, the proteome characterization from the skin secretion has shown a significant difference between the compositions of the antimicrobial peptides for this species, reinforcing the doubt on the taxonomy of this group denominated as species complex. 
Table 1. Sequence comparison among leptodactylid peptides.

\begin{tabular}{|c|c|}
\hline Peptides & Sequences \\
\hline Ocellatin-1 & GVVDILKGAGKDLLAHLVG- ISEKV- $\mathrm{NH}_{2}$ \\
\hline Ocellatin-1.1 & GVVDILKGAGKDLLAH - - - - - - - \\
\hline Ocellatin-2 & GVLDIFKDAAKQILAHAAEQI - - - - $\mathrm{NH}_{2}$ \\
\hline Ocellatin-2.1 & GVLDIFKDAAKQLLIA - - - - - - - - \\
\hline Ocellatin-3 & GVLDILKNAAKNILAHAAEQI - - - - $\mathrm{NH}_{2}$ \\
\hline Ocellatin-3.1 & GVLDILKNAAKNILA - - - - - - - - \\
\hline Ocellatin-4 & GLLDFVTGVGKDIFAQLIKQI - - - - $\mathrm{NH}_{2}$ \\
\hline Ocellatin- 5 & AVLDILKDVGKGLLSHFMEKV - - - - $\mathrm{NH}_{2}$ \\
\hline Ocellatin-5.1 & AVLDILKDVGKGLL- - - - - - - - - \\
\hline Ocellatin- 6 & AVLDFIKAAGKGLVTNIMEKVG - - - $\mathrm{NH}_{2}$ \\
\hline Ocellatin- 6.1 & AVLDFIKAAGKGLVTNIM- - - - - - \\
\hline Laticeptin & GVVDILKGAAKDLAGHLATKVMNKL - $\mathrm{NH}_{2}$ \\
\hline Fallaxin & GVVDILKGAAKDIAGHLASKVMNKL - $\mathrm{NH}_{2}$ \\
\hline Pentadactylin & GLLDTLKGAAKNVVGSLASKVMEKL - $\mathrm{NH}_{2}$ \\
\hline Syphaxin & GVLDILKGAAKDLAGHVATKVINKI - $\mathrm{NH}_{2}$ \\
\hline $\begin{array}{l}\left(-\mathrm{NH}_{2}\right) \text { - C-terminu } \\
(\mathrm{Bold})-\text { Peptides }\end{array}$ & \\
\hline
\end{tabular}

Shaded letters represent identical peptides and bold letters represent conservative substitutions.

Antimicrobial Activity

The MICs for ocellatins- 5 and -6 against reference strains of Gram-negative and -positive microorganisms were as follows: $E$. coli, 64 and $32 \mu \mathrm{g} / \mathrm{mL}$, respectively; S. aureus, 128 and $64 \mu \mathrm{g} / \mathrm{mL}$, respectively (Fig. 3). This means that the small change in the last amino acid residue caused a great change in the biological activity. Interestingly, the homologous peptide fallaxin (L. fallax) was not active against the Gram-positive bacterium $S$. aureus or against the yeast $C$. albicans at concentrations below $160 \mu \mathrm{M}$ (Rollins-Smith et al., 2005), suggesting that the differentiated Nterminus of ocellatins of this study could render the peptide with a higher activity.

There are other studies where the activity of the fragments has been observed, confirming the lower antimicrobial activity for the peptides of this family, correlating a higher activity to the presence of amidation at the C-terminal and to an increase in the molecular mass-except for the fallaxin peptide (1-22), which exhibited a moderate activity against $S$. aureus.

The integral whole and amidated peptides (ocellatins- 5 and -6) were present in low amounts in the skin secretions so that, despite their relatively low potency, their concentration may exceed the MIC value for many pathogens to which the animal may be exposed in the wild. Compared with many other frog skin antimicrobial peptides (Conlon, 2004), these data suggest that the protection against invasive microorganisms can be related to a synergistic effect between the whole peptides and their fragments, owing to this low biological activity of the individual molecules. It is possible that the truncated forms of ocellatins are enzymatically processed products, cleaved by a skin enzyme. Magaininase, an endopeptidase found in the skin of Xenopus laevis, recognizes peptides that adopt an amphipathic $\alpha$-helical motif, longer than 12 residues and with one strongly hydrophobic face (Resnick et al., '91).

There are no consensus regarding the amino acid sequences of the frog skin antimicrobial peptides, which are associated with biological activity but are almost invariably cationic, relatively hydrophobic and have the propensity to form an amphipathic $\alpha-$ helix in a membrane-mimetic environment (Tossi et al., 2000; Rollins-Smith et al., 2005). The potency of a particular peptide against microorganisms is determined by a complex interaction between factors relating to conformation (degree of helicity), net charge, hydrophobicity and amphipathicity (Yeaman and Yount, 2003).

\section{Biochemical Insight into Phylogenetic Relationships}

According to morphological characteristics, the leptodactylids are distributed in four groups: L. syphax, L. laticeps and L. fallax are in the $L$. pentadactylus group and $L$. ocellatus is in its own group (Frost, 2008). The most closely related Leptodactylus antimicrobial peptides were grouped into three clusters (Fig. 4). A full understanding of the phylogenetic relationships of this group will only be clear with a complete study that includes not only morphological data but also molecular and ecological information.

Since the basis of the observation that the structural organization of the precursors of antimicrobial peptides belonging to different families is quite similar, it has been speculated that many frog skin antimicrobial peptides arose from a common ancestral gene (Duda et al., 2002). The molecular diversity in the present-day species would be a consequence of multiple 

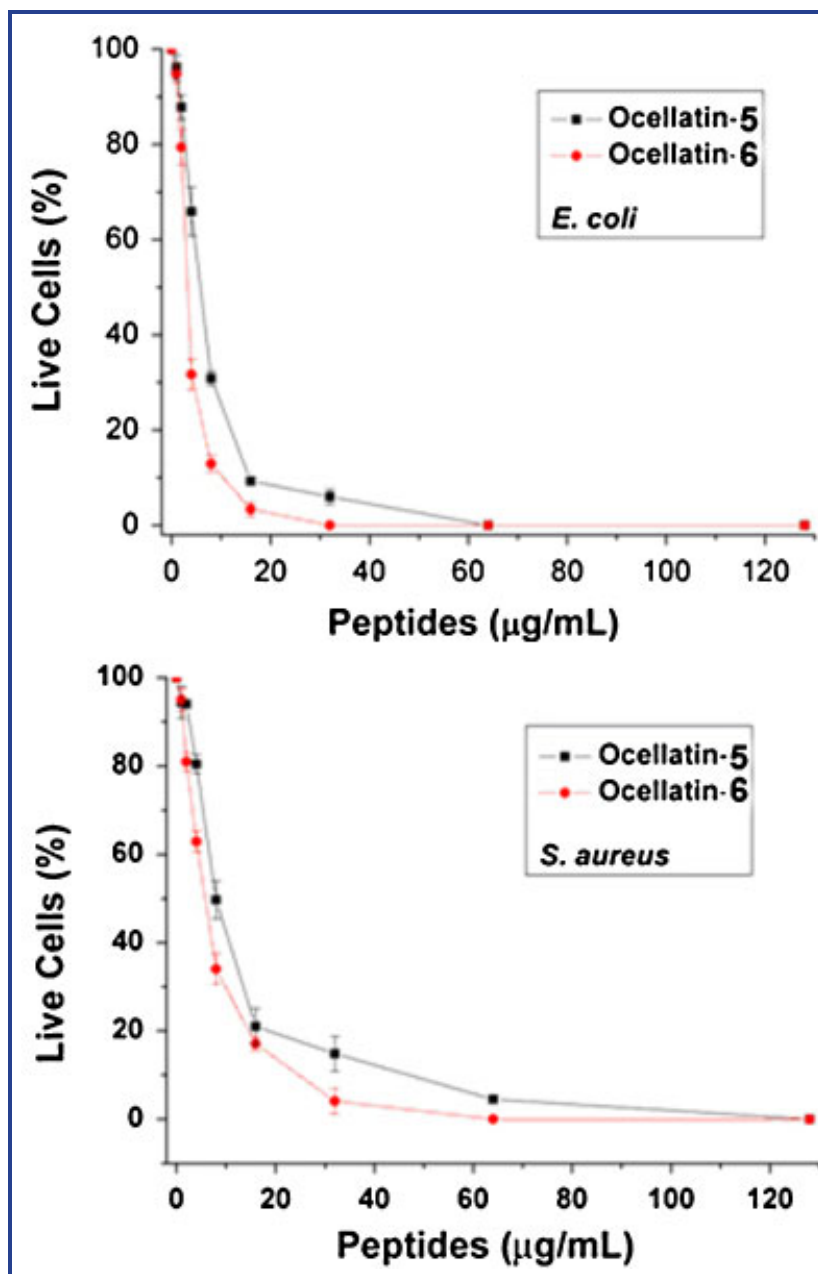

Figure 3. Concentration-response curves of the ocellatins on the growth inhibition of two bacteria species. The initial inoculum was $2.5 \times 10^{8} \mathrm{CFU} / \mathrm{mL}$ (colony forming units per milliliter). The assay was performed in triplicate and the bars indicate the standard deviation.

duplications and mutations of this ancestral gene during radiation of the species and within individual species (Vanhoye et al., 2003).

Selective pressure has acted to conserve the N-terminal proregion, whereas the C-terminal functional region has rapidly evolved pathogens (Mor et al., '94; Nicolas and Mor, '95). It has been speculated that a mutagenic, error-prone DNA polymerase similar to $E$. coli Pol V may be involved in this accelerated rate of molecular evolution (Conlon et al., 2004). At this time, there has been no biological activity reported for the $\mathrm{N}$-terminal flanking peptide. Hence, one is entitled to question whether the biological role of "antimicrobial peptides" described in this article really is to protect against microorganisms and whether synthesis confers a significant advantage to the animal.

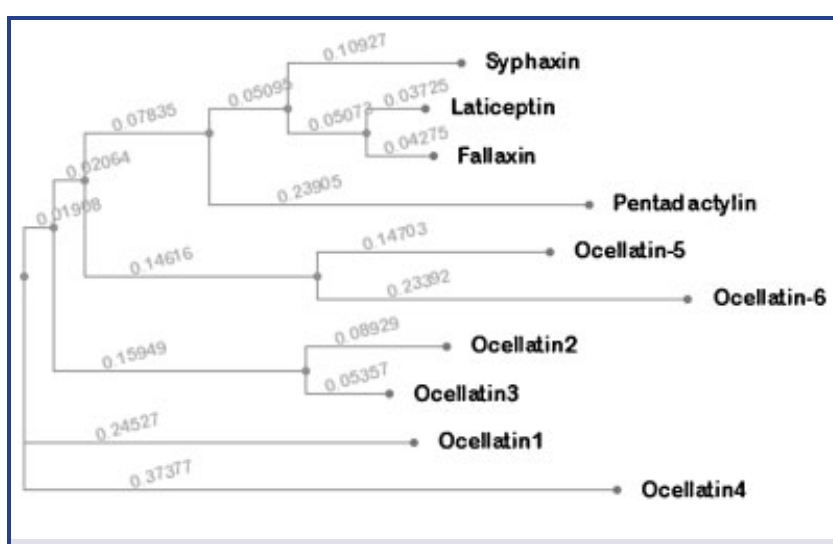

Figure 4. Phylogram built at Clustal $W$ tool to similar peptides. The phylogram estimates a phylogeny among peptides and the branch lengths are proportional to the amount of inferred evolutionary change. Peptides found in Leptodactylus pentadactylus group form a cluster. Other cluster is formed by ocellatins (Leptodactylus ocellatus group). Pentadactylin, found with fallaxin in the Leptodactylus pentadactylus, is separated.

Evidence in favor of a protective role is provided by the observation that many of the frog skin antimicrobial peptides isolated from ranid frogs are active in vitro against the pathogens to which the frog may be exposed in the wild (Conlon et al., 2004).

The cladogram analysis based on the primary sequence of the antimicrobial peptides described in this family showed the separation of $L$. ocellatus into two groups: a group that secretes ocellatins- 1 to -4 and another one producing ocellatins- 5 and -6 . The first group was collected and analyzed in a central region of Brazil, in a savannah environment, and the second was collected in a sand bank in a fragment of the coastal Atlantic Forest. These species exhibit some morphological variations (Fig. 1C and D). These molecular data may help to corroborate the hypothesis that this group is in fact a species complex in which the species of the Brazilian savannah could be L. macrosternum, with morphological characteristics very similar to those of $L$. ocellatus. However, a taxonomic study is still necessary as phenotypic variations may not be determining for speciation.

It is noteworthy that a great variation between bioactive peptides from the skin secretion of anurans has never been seen, specially regarding antimicrobial peptides in the same species, such as the dermaseptins of the Phyllomedusa hypochondrialis (Brand et al., 2006); in addition, the skin secretion of specimens of $L$. macrosternum has been extracted by our group and none of the ocellatins has been found (data not shown).

In a recent study, Hedges and Heinicke (2007) have shown, by molecular phylogeny based on mitochondrial DNA analysis, the convergence of molecular with morphological data. It has been suggested that L. albilabris, species widely distributed in the 

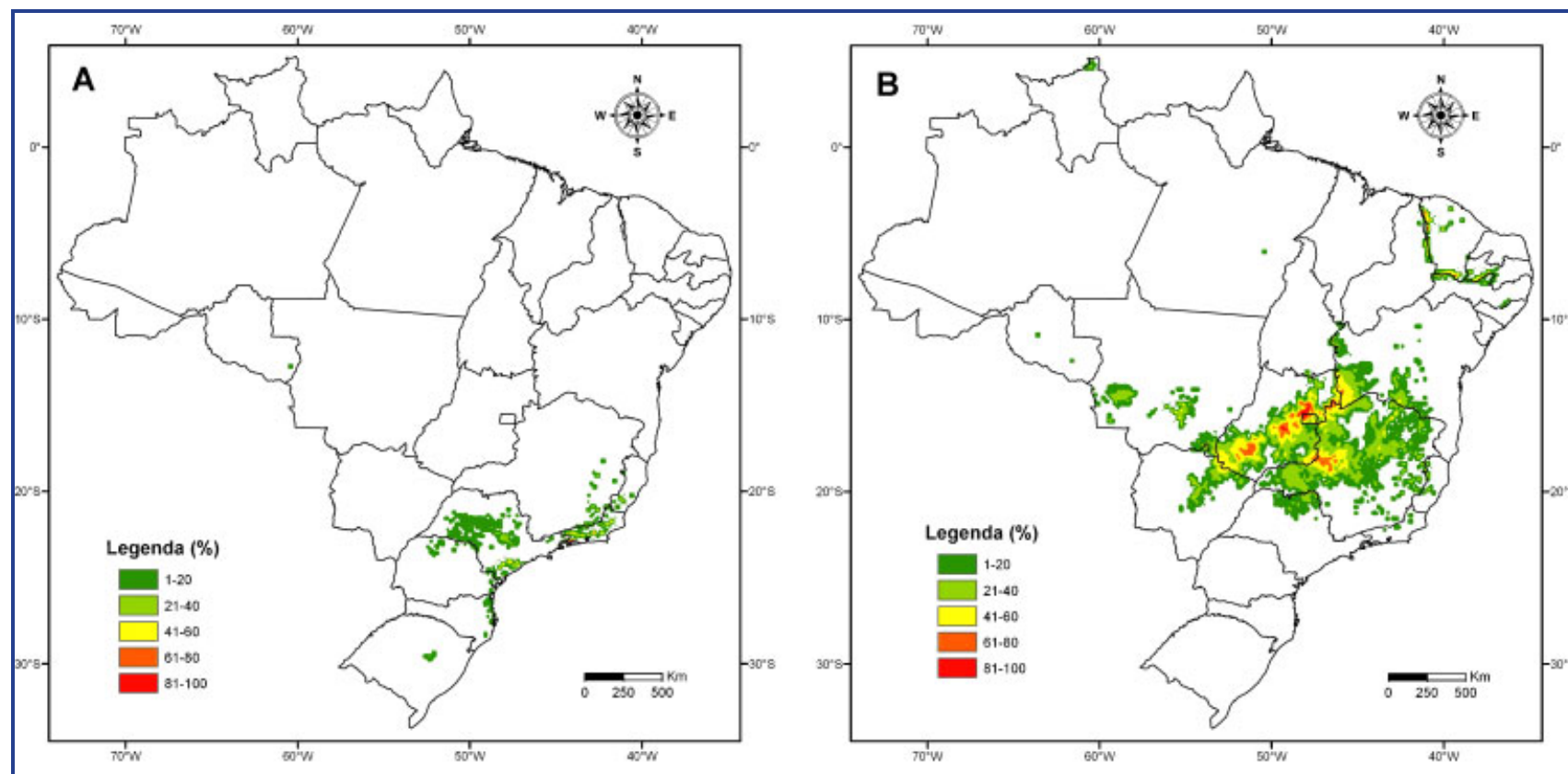

Figure 5. Map of the Brazil, illustrating predictive ecological niche modeling of Leptodactylus ocellatus. GARP modeling of the ecological niche of species using only bioclimatic variables in Brazilian savannah (A) and Marambaia Island (B). Twenty experiments were analyzed with GIS ArcView 3.2 to obtain the overlap index, where high equals $100 \%$ coincidence and low equals $<20 \%$, shown in color scale gradient. The pixel area is equivalent to $1 \mathrm{~km}^{2}$. GARP, Genetic Algorithm for Rule-Set Prediction; GIS, geographic information system.

Caribbean Islands such as Puerto Rico, is, in fact, a species complex. These results confirm the biogeographical data as this species is distributed in a geographic isolated archipelago, a factor that could be associated with the speciation of this group.

In an analysis with environmental modeling algorithms, several abiotic parameters were studied and related to the habitat of the specimens collected in this study, the group ocellatus, and compared with the data of the Brazilian savannah (Fig. 5). We can observe in the density map that the farther the distance from the Brazilian savannah and the Atlantic Forest areas, the lower the probability of finding the species with the same environmental characteristics.

Studies on antimicrobial peptides, in addition to help in the classic "odyssey" in the search for new animal products in an attempt to the development of new drugs, also promote the understanding of the maintenance of these animals in environments where there is a constant fight against commensal microorganisms. From a different perspective, this class of molecules is an important tool in the phylogeny, biogeography and evolution for the construction of the natural history of this group.

\section{ACKNOWLEDGMENT}

The corresponding author was supported by a fellowship from $\mathrm{CNPq}$ (Universal), a Brazilian Government financing agency. This work was partially financed by grants from
Empresa Brasileira de Pesquisa Agropecuária (EMBRAPA, Brasília, Brazil).

\section{LITERATURE CITED}

Brand GD, Leite JRSA, Silva LP, Albuquerque S, Prates MV, Azevedo RB, Carregaro V, Silva JS, Sa VC, Brandão RA, Bloch Jr C. 2002. Dermaseptins from Phyllomedusa oreades and Phyllomedusa distincta: anti-Trypanosoma cruzi activity without cytotoxicity to mammalian cells. J Biol Chem 277:49332-49340.

Brand GD, Leite JRSA, Mandel SMS, Mesquita DA, Silva LP, Prates MV, Barbosa EA, Vinecky F, Martins GR, Galasso JH, Kuckelhaus SA, Sampaio RN, Furtado Jr JRA, Andrade AC, Bloch Jr C. 2006. Novel dermaseptins from Phyllomedusa hypochondrialis (Amphibia). Biochem Biophys Res Commun 347:739-746.

Carvalho ALG, Silva HR, Araujo AFB, Alves-Silva R, Silva-Leite RR. 2007. Feeding ecology of Tropidurus torquatus (Wied) (Squamata, Tropiduridae) in two areas with different degrees of conservation in Marambaia Island, Rio de Janeiro, Southeastern Brazil. Rev Bras Zool 24:222-227.

Conlon JM. 2004. The therapeutic potential of antimicrobial peptides from frog skin. Rev Med Microbiol 15:1-9.

Conlon JM, Kolodziejek J, Nowotny N. 2004. Antimicrobial peptides from ranid frogs: taxonomic and phylogenetic markers and a potential source of new therapeutic agents. Biochim Biophys Acta 1696:1-14. 
Conlon JM, Al-Ghaferi N, Abraham B, Sonnevend A, King JD, Nielsen PF. 2006. Purification and properties of laticeptin, an antimicrobial peptide from skin secretions of the South American frog Leptodactylus laticeps. Protein Pept Lett 13:355-359.

Costa JA, Peterson T, Beard CB. 2002. Ecologic niche modeling and differentiation of populations of Triatoma brasiliensis neiva, 1911, the most important chagas' disease vector in northeastern brazil (hemiptera, reduviidae, triatominae). Am J Trop Med Hyg 67:516-520.

De la Riva I, Maldonado M. 1999. First record of Leptodactylus ocellatus (Amphibia, Anura, Leptodactylidae) in Bolivia and comments on related species. Graellsia 55:193-197.

Dourado FS, Leite JRSA, Silva LP, Melo JAT, Bloch Jr C, Schwartz EF. 2007. Antimicrobial peptide from the skin secretion of the frog Leptodactylus syphax. Toxicon 50:572-580.

Duda Jr TF, Vanhoye D, Nicolas P. 2002. Roles of diversifying selection and coordinated evolution in the evolution of amphibian antimicrobial peptides. Mol Biol Evol 19:858-864.

Frost DR. 2008. Amphibian species of the world: an online reference. Version 4, 31 July. Electronic database accessible at: http:// research.amnh.org/herpetology/amphibia/index.phpS. American Museum of Natural History, New York.

Gallardo JM. 1964. Consideraciones sobre Leptodactylus ocellatus (L.) (Amphibia, Anura) y especies aliadas. Physis 24:373-384.

Gogichaeva NV, Williams T, Alterman MA. 2007. MALDI TOF/TOF tandem mass spectrometry as a new tool for amino acid analysis. Mass Spectrom 18:279-284.

Hedges SB, Heinicke MP. 2007. Molecular phylogeny and biogeography of West Indian frogs of the genus Leptodactylus (Anura, Leptodactylidae). Mol Phylogenet Evol 44:308-314.

Heyer WR, Reid YR . 2003. Does advertisement call variation coincide with genetic variation in the genetically diverse frog taxon currently known as Leptodactylus fuscus (Amphibia: Leptodactylidae)? An Acad Bras Cienc 75:39-54.

Hoffmann FC, Janeway KCA, Ezekowitz RA. 2007. Phylogenetic perspectives in innate immunity. Science 284:1313-1318.

IUCN. 2008. Global amphibian assessment. Available at: http:// www.globalamphibians.org (accessed on 30 July 2008).

King JD, Al-Ghaferi N, Abraham B, Sonnevend A, Leprince J, Nielsen PF, Conlon JM. 2005. Pentadactylin: an antimicrobial peptide from the skin secretions of the South American bullfrog Leptodactylus pentadactylus. Comp Biochem Physiol 141:393-397.

Lai $H$, Liu $H$, Lee WH, Zhang Y. 2001. A novel bradykinin-related peptide from skin secretions of toad Bombina maxima and its precursor containing six identical copies of the final product. Biochem Biophys Res Commun 286:259-263.
Menezes LFT, Araújo DSD. 2005. Formações vegetais da Restinga de Marambaia. In: Menezes LFT, Peixoto AL, Araújo DSD. Historia natural da Marambaia. Seropédica: ADUR. 288p.

Mor A, Hani K, Nicolas P. 1994. The vertebrate peptide antibiotics dermaseptins have overlapping structural features but target specific microorganisms. J Biol Chem 269:31635-31641.

Nascimento AC, Zanotta LC, Kyaw CM, Schwartz EN, Schwartz CA, Sebben A, Sousa MV, Fontes W, Castro MS. 2004. Ocellatins: new antimicrobial peptides from the skin secretion of the South American frog Leptodactylus ocellatus (Anura: Leptodactylidae). Protein J 23:501-508.

Nascimento AC, Chapeaurouge A, Perales J, Sebben A, Sousa MV, Fontes W, Castro MS. 2007. Purification, characterization and homology analysis of ocellatin-4, a cytolytic peptide from the skin secretion of the frog Leptodactylus ocellatus. Toxicon 50: 1095-1104.

National Committee for Clinical Laboratory Standards. 1999. Performance standards for antimicrobial susceptibility testing, NCCLS-approved standard M100-S9, National Committee for Clinical Laboratorial Standards, Wayne, PA.

Nicolas P, Mor A. 1995. Peptides as weapons against microorganisms in the chemical defense system of vertebrates. Annu Rev Microbiol 49:277-304.

Peterson AT. 2001. Predicting species' distributions based on ecological niche modeling. Condor 103:599-605.

Resnick NM, Maloy WL, Robert Guy H, Zasloff M. 1991. A novel endopeptidase from Xenopus that recognizes a-helical secondary structure. Cell 66:541-554.

Rollins-Smith LA, King JD, Nielsen PF, Sonnevend A, Conlon JM. 2005. An antimicrobial peptide from the skin secretions of the mountain chicken frog Leptodactylus fallax (Anura: Leptodactylidae). Regul Pept 124:173-178.

Saitou N, Nei M. 1987. The neighbor-joining method: a new method for reconstructing phylogenetic trees. Mol Biol Evol 4:406-425.

Tossi A, Sandri L, Giangaspero A. 2000. Amphipathic, $\alpha$-helical antimicrobial peptides. Biopolymers 55:4-30.

Vanhoye D, Bruston F, Nicolas P, Amiche M. 2003. Antimicrobial peptides from hylid and ranin frogs originated from a 150-millionyear-old ancestral precursor with a conserved signal peptide but a hypermutable antimicrobial domain. Eur J Biochem 270: 2068-2081.

Williams GT, Alterman A. 2007. MALDI-TOF/TOF tandem mass spectrometry as a new tool for amino acid analysis. J Am Soc Mass Spectrom 18:279-284.

Yeaman MR, Yount NY. 2003. Mechanisms of antimicrobial peptide action and resistance. Pharmacol Rev 55:27-55. 